\title{
Fertilization of a Native Grassland in the 'Depresión del Rio Salado', Province of Buenos Aires: Herbage Dry Matter Accumu- lation and Botanical Composition
}

\author{
H.D. GINZO, MARTA COLLANTES, AND O.H. CASO
}

\section{Abstract}

The objective of this study was the evaluation of herbage production and botanical composition of a native grassland, ("flechillar"), of the Salado River Basin fertilized, during 3 years, with 0 , 381 , or $762 \mathrm{~kg} \cdot \mathrm{ha}^{-1} \cdot \mathrm{yr}^{-1}$ of ammonium sulphate alone or combined with 0 or $208 \mathrm{kgha}^{-1} \cdot \mathrm{yr}^{-1}$ of triple superphosphate. Annual dry matter accumulation of herbage, (ADMA), was restricted by a negative water-balance in the soil during the first experimental year. A linear response to ammonium sulphate rate, irrespective of triple superphosphate, was observed. In the following years the relationship between ADMA and ammonium sulphate became progressively quadratic, and it was manifest firstly in the plots fertilized with superphosphate. The response to superphosphate seemed to be due to an environmentally stimulated growth demand more than to a phosphorus deficiency in the soil. Ammonium sulphate promoted the growth of graminoids and decreased that of legumes and forbs. Superphosphate increased the proportion of legumes and ameliorated the detrimental effect of ammonium sulphate, but only few species reflected the effect of fertilization. Because (a) the sward reacted remarkably to the addition of a nitrogenous fertilizer, and (b) its main legume species, Medicago polymorpha, (annual), was scarce, it is suggested that the sward's herbage production could be substantially increased by its enrichment with perennial legumes provided that their growth and expansion were assisted by periodic additions of a phosphorous fertilizer.

The so-called 'Depresión del Río Salado,' best translated as 'Salado River Basin,' is a vast area of about $58.000 \mathrm{~km}^{2}$ in the Province of Buenos Aires, Argentina.

Its shape is almost triangular; the base extends from (approximately) $34^{\circ} 50^{\prime} \mathrm{S}, 57^{\circ} 55^{\prime} \mathrm{W}$ to $38^{\circ} 00^{\prime} 57^{\circ} 35^{\prime} \mathrm{W}$ along the coast, and its vertex lies somewhere near $36^{\circ} 30^{\prime} \mathrm{S}, 61^{\circ} 10^{\prime} \mathrm{W}$ (Vervoorst 1967) (Fig. 1).

Since the introduction of English cattle breeds in the last century, the main agricultural enterprise in the Basin has been cattle production on the basis of continuous stocking of native grasslands (Vervoorst 1967). These account for $70 \%$ of the Basin's area. In the course of the last two decades, however, there has been an increasing trend to a mixed kind of livestock management: breeding and fattening. In order to fatten steers in the same farms, cattlemen increased forage production through the substitution of cultivated perennial grasslands for the native ones. However, this action has been taken without assessing, as a first step, the production potential of some of the best native grasslands of the region. We consider the best grasslands because not all of them are suitable for steer fattening; e.g. those thriving on solonetzic soils (Ginzo et al. 1980).

Authors are research scientists, Centro de Ecofisiologia Vegetal (FECIC CONICET-Fund. M. LILLO), Serrano 661, 1414 Capital Federal, R. Argentina.

Authors wish to acknowledge Dr. Raúl Arraras Vergara for having permitted the conduction of the present trial in his farm "El Transito" and Ings. Agrs. E. Myers, R. Mendoza, and Mariana Kade for their invaluable help in the collection of data.

Manuscript received April 18, 1980.

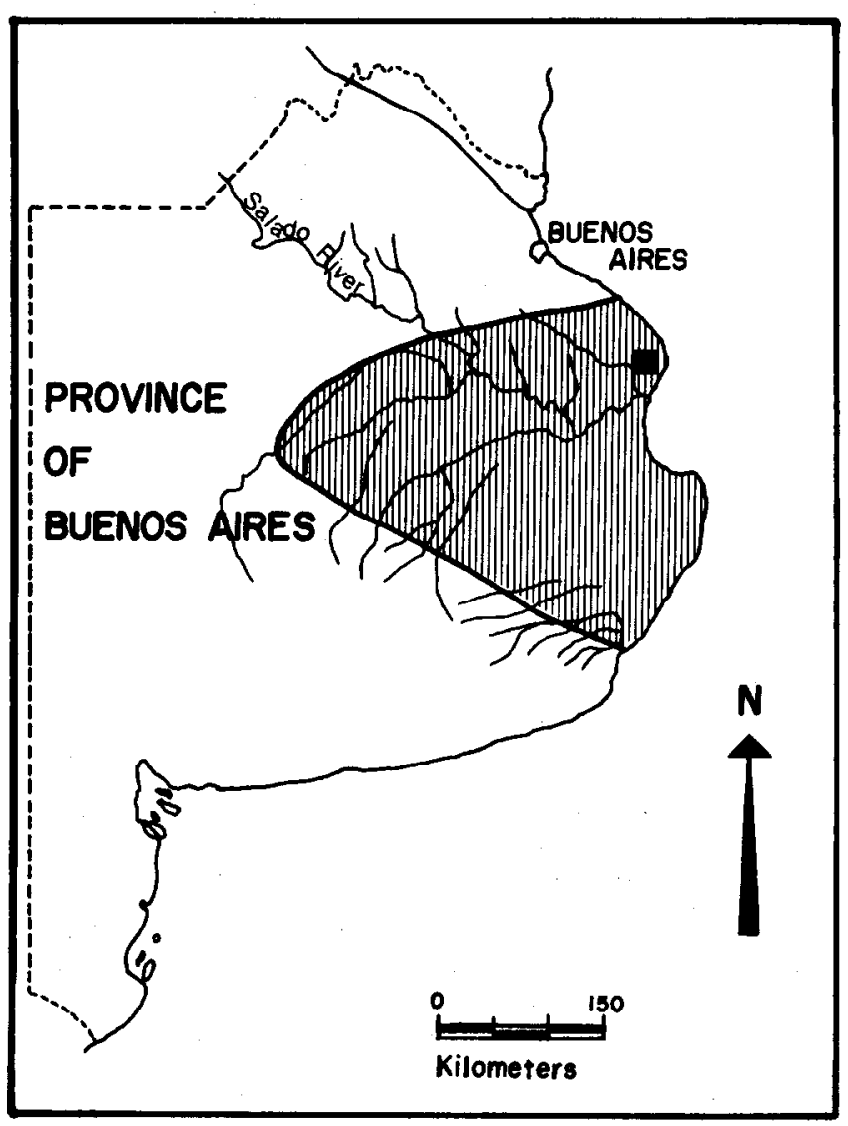

Fig. 1. The Salado River Basin (greyed), (After Vervoorst 1967). The approximate location of the experimental site is represented by the black square.

In view of the foregoing we decided to determine the production potential of a "flechillar," one of the most productive herbaceous communities of the Basin (Vervoorst 1967), through its fertilization with ammonium sulphate and triple superphosphate. It deserves mentioning that some of the Basin's native swards have been fertilized particularly with phosphorous sources (Vida, Aponte, pers. comm. 1975), and, on the whole, substantial increments in meat production have been observed.

We chose ammonium sulphate and triple superphosphate because they are sources of most of the major nutrients needed for an active plant growth. As it is well known that chemical fertilization may alter the botanical composition of a grassland (Thurston 1969; Rogler and Lorenz 1974; Rabotnov 1977), we also evaluated the fate of some of the most conspicuous species of the "flechillar." 


\section{Materials and Methods}

The experimental site was located near the town of Verónica $\left(35^{\circ} 24^{\prime} \mathrm{S}, 57^{\circ} 20^{\prime} \mathrm{W}\right)$, (Fig. 1). The monthly distributions of rainfall and mean air temperature from September 1975 to October 1978 are represented in Figure 2. That figure also depicts the soil-water balance as calculated by Thornthwaite and Mather's (1957) method. Rainfall and temperature were recorded at Punta de Indio $\left(35^{\circ} 18^{\prime} \mathrm{S}, 56^{\circ} 15^{\prime} \mathrm{W}\right), 25 \mathrm{~km}$ away from the experimental site. The experimental site consisted of a fenced homogeneous stand of a native grassland, which botanical composition (Table 1) was very similar to that of a "flechillar"(Vervoorst 1967), Mizczynski (pers. comm. 1978) classified the site's soil as Vertic Argiudol ( $\mathrm{pH}=6.5$; E.C. $=0.7 \mathrm{mmho} / \mathrm{cm}$ in the $0-0.2 \mathrm{~m}$ layer).

Commercial ammonium sulphate $(21 \% \mathrm{~N}, 24 \% \mathrm{~S})$ and triple superphosphate $\left(46 \% \mathrm{P}_{2} \mathrm{O}_{5}\right)$ were applied, respectively, at the following annual rates $\left((\mathrm{kg}-\mathrm{kg}) \cdot \mathrm{ha}^{-1}\right): 0-0,0-208,381-0,381-208$, 762-0, and 726-208. Each fertilizer combination was broadcast by hand twice each year: $70 \%$ of the annual rate in spring (10-17-75, $10-1-76$ and $10-7-77)$, and the remaining $30 \%$ in autumn (4-7-76, 3-16-77 and 3-30-78).

The fertilizer treatments were arranged in six randomized blocks. Each experimental plot was $4 \mathrm{~m}$ square and included a $2-\mathrm{m}$ square centered subplot. Herbage samples were taken from the subplot. The area to be sampled was demarcated by an iron frame of $1.0 \times 0.1 \mathrm{~m}$. Herbage was clipped to $0.03 \mathrm{~m}$ height. A plot sample was composed of four subsamples of $0.21 \mathrm{~m}^{2}$ each. The first position of the frame in the subplot was chosen at random; the other three positions were selected in such a way that no one overlapped with the preceding. Each plot was mown to $0.03 \mathrm{~m}$ with a garden flail-mower after sampling. Hay was raked away from the plots thereafter.

The frequency of sampling was determined by the sward's intensity of regrowth, particularly that of the plots fertilized with the highest doses of ammonium sulphate and triple superphosphate. Usually the experiment was sampled when the height of the canopy was between 0.1 and $0.15 \mathrm{~m}$. Each sample was separated into graminoids, (grasses and sedges), legumes and forbs in the laboratory. Fractionation of the first seven harvests was made after ovendrying at $80^{\circ} \mathrm{C}$. After having noticed that the fractionation of fresh material was both easier and more precise with fresh material, herbage samples were stored at $-20^{\circ} \mathrm{C}$ until fractionation and ovendried at $80^{\circ} \mathrm{C}$ thereafter.

Fifteen harvests were made during the 36 months of this study. Three, six, and five harvests were taken in the course of the first, second, and third experimental years, respectively. These years were arbitrarily chosen to extend from October 17, 1975, to October 1, 1975; October 1, 1976, to October 7, 1977, and October 7, 1977, to October 18, 1978.

The harvests of each year were added and dry matter yield was expressed as annual dry matter accumulation (ADMA), as suggested by Hodgson (1979).

Phytosociological surveys were made before (9-25-75) the first and after (11-29-78) the last addition of fertilizers. A list of species for each plot was compiled and to each species particular frequency and cover-abundance values, as defined by Braun-Blanquet (1950) were assigned. A symbol $\mathrm{N}^{\mathrm{n}}$ was employed for representing the frequency, $N$, and the cover-abundance, $n$, scales.

Soil $\mathrm{pH}$ was measured on soil samples taken at depths of 0.05 , 0.1 , and $0.2 \mathrm{~m}$. They were quickly wetted with distilled water. Before $24 \mathrm{~h}$ had elapsed, the soil was pasted for electrometric measurement of pH (Jackson 1964). Significant differences between means were evaluated by cluster analysis (Gates and Bilbro 1978).

\section{Results}

We shall not present the data corresponding to the individual samplings of herbage and soil $\mathrm{pH}$ because the quantitative effect of fertilization was clouded, in some occasions, by unknown seasonal influences. These, however, did not affect the qualitative effect of fertilization.

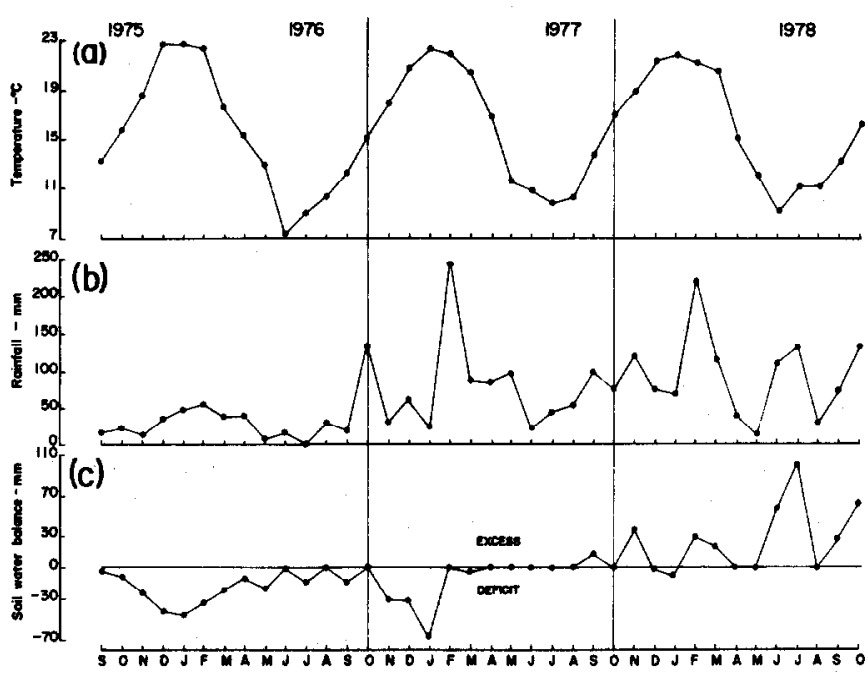

Fig. 2. Average monthly values of mean air temperature, rainfall, and soil-water balance for Punta de Indio, $25 \mathrm{~km}$ away from the experimental site.

Table 1. Main species of the "Nechillar" at the beginning of the experimental period. Survey made in September 25, 1975.

Species Braun-Blanquet's Index ${ }^{1}$

Gaudinia fragilis (L.) Beauv.

Dallisgrass (Paspalum dilatatum Poir.)

Piptochaetium bicolor (Vahl.) Desv.

Bothriochloa laguroides (DC.) Pilg.

Phalaris aquatica L.

Panicum decipiens Ness.

Stipa neesiana Trin. et Rupr.

Black medic (Medicago polymorpha L.)

Hypochoeris spp. $\mathrm{L}$.

Cerastium glomeratum Thill

Plumeless thistle (Carduus acanthoides L.)

Oxalis martiana Zucc
$\mathrm{V}^{3}$

$\mathrm{V}^{2}$

VI

VI

VI

VI

IVI

$\mathrm{V}$

VI

IV'

IV

IV
I Frequency scale. V: $80.1-100 \%$; IV: 60.1-80\%; 111: 40. I-60\%; II: $20.1-40 \%$; I: up to $20 \%$.

Cover-abundance scale. 5: any number of plants, with cover $>75 \%$ of the reference area; 4 : ibid, with cover $50-75 \%$; 3 ; ibid, with cover $25-50 \%$; $2:$ ibid, with cover $5-25 \%$; I: numerous plants, but cover $<5 \%$; or scattered plants, with cover $<5 \%$; + : few plants, with small cover.

The annual additions of ammonium sulphate increased herbage ADMA, although the shape of the relationship varied with time and triple superphosphate fertilization (Fig. 3). The ADMA response to ammonium sulphate was linear and independent of superphosphate in the first year. The amount of herbage harvested per unit of ammonium sulphate was about $24 \mathrm{~kg} / \mathrm{kg}$. This rate was $50 \%$ lower than that calculated for the no-superphosphate plots in the following year. In the second year ADMA was quadratically related to ammonium sulphate in the plots which had been fertilized with superphosphate. A quadratic function also described the ADMA-ammonium sulphate relationship in the third year and it was independent of triple superphosphate rate.

Average annual values for the components of the sward's gross botanical composition are presented in Tables 2 and 3. Before fertilization the botanical composition of the "flechillar," on a weight basis, was: $96 \%$ graminoids, $2 \%$ legumes, and $2 \%$ forbs. Fertilization did not modify the relative amount of graminoids in the sward in the first year; it did so, and particularly the addition of ammonium sulphate, in the following years (Table 2). However, the effect of ammonium sulphate in the second and third years differed in that there was a conspicuous linear trend in the propor- 
Table 2. Average relative amount (\% weight) of graminoids as affected by fertilization.

\begin{tabular}{|c|c|c|c|c|c|c|c|c|}
\hline \multirow{2}{*}{$\frac{\text { Period }}{10 / 17 / 75-4 / 7 / 76}$} & \multirow{2}{*}{$\frac{0-0}{76.10^{\mathrm{a}}}$} & \multirow{2}{*}{$\begin{array}{l}0-208 \\
84.50^{\mathrm{a}}\end{array}$} & $\begin{array}{r}\text { Fer } \\
381-0\end{array}$ & $\begin{array}{l}\text { ombinatic } \\
381-208 \\
0^{1}\end{array}$ & $762-0$ & $762-208$ & mean & S.E. \\
\hline & & & $81.14^{\mathrm{a}}$ & $82.6 T^{2}$ & $84.16^{\mathrm{a}}$ & $85.50^{\mathrm{a}}$ & 82.35 & 3.58 \\
\hline $10 / 1 / 76-4 / 26 / 77$ & $79.49^{\mathrm{h}}$ & $76.15^{\mathrm{a}}$ & $82.28^{b}$ & $81.61^{\mathrm{b}}$ & $87.57^{\mathrm{b}}$ & $85.62^{\mathrm{b}}$ & 82.19 & 2.119 \\
\hline $10 / 7 / 77-10 / 18 / 78$ & $58.90^{\circ}$ & $59.68^{\mathrm{a}}$ & $72.44^{\mathrm{b}}$ & $71.91^{b}$ & $78.18^{b}$ & $76.26^{b}$ & 69.56 & 4.498 \\
\hline
\end{tabular}

Means in a row supervised by the same letter are not significantly different at $\alpha=0.05$.

larcsine transform of percent values.

tion of graminoids during the second year but not in the third one. In general, superphosphate did not affect the graminoid fraction. There was an overall decrease in the relative amount of graminoids- which was particularly noticeable in the plots not fertilized with ammonium sulphate-in the third year.

The variation of the "forbs" fraction was complementary of that of the graminoid fraction because the former was the other large component of the sward, except in the spring of 1976. Consequently, we do not present its values for the samples in which graminoids and forbs were the only components of the sward. The relatively amount of forbs was depressed by ammonium sulphate more or less independently of its proportion in the sward (Table 3). Actually, even in the presence of legumes, the proportion of forbs mainly depended on that of graminoids.

The proportion of legumes was increased by triple superphosphate and adversely affected by ammonium sulphate (Table 3 ). Nevertheless, the particular combination of $381 \mathrm{kgeha}^{-1} \cdot \mathrm{yr}^{-1}$ of ammonium sulphate with $208 \mathrm{~kg}^{-1 a^{-1}} \cdot \mathrm{yr}^{-1}$ of triple superphosphate resulted in relative amounts equal to (third year) or higher (second year) than those of the control treatment. The highest rate of ammonium sulphate was definitely harmful to legume growth.

In the course of the 38 months elapsed between the phytosociological surveys the populations of relatively few species showed conspicuous changes in size and density resulting from the fertilization regime imposed to the experimental grassland. (Table 4). The frequency of Dallisgrass (Paspalum dilatatum) was neither modified by ammonium sulphate nor by triple superphosphate; its cover-abundance value (density) was, however, slightly increased by ammonium sulphate, independently of superphosphate fertilization. Ammonium sulphate tended to increase both the frequency and density of Phalaris aquatica, particularly in the absence of triple superphosphate. The frequency of Piptochaetium bicolor was unaffected by fertilization; ammonium sulphate, however, increased slightly its density and the effect was more noticeable in the absence of superphosphate. Fertilization did not affect the density of Stipa neesiana, but it extended its population. In this respect, the effect of superphosphate was more conspicuous than that of ammonium sulphate. Both ammonium sulphate and triple

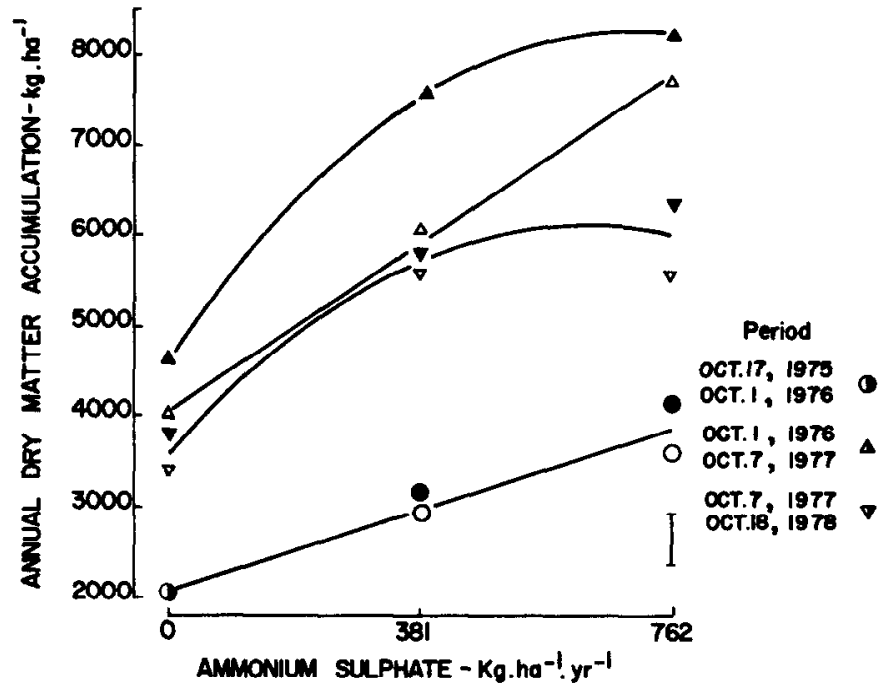

Fig. 3. Herbage annual dry matter accumulation of a "flechillar" as affected by ammonium sulphate and triple superphosphate. Open symbols: no-superphosphate. Closed symbols: 208 kgosuperphosphate ${ }^{-1}{ }^{-1}$ $\bullet y r^{-1}$.

Table 3. Average relative amounts (\% weight) of legumes and forbs as affected by fertilization.

\begin{tabular}{|c|c|c|c|c|c|c|c|c|}
\hline Sampling dates & $0-0$ & $0-108$ & $\begin{array}{r}\text { Fert } \\
381-0 \\
1 \\
\mathrm{~s}\end{array}$ & $\begin{array}{l}\text { ombinatio } \\
381-208 \\
\text { s } \\
1 \\
\end{array}$ & $762-0$ & $762-208$ & mean & S.E. \\
\hline $\begin{array}{c}\text { Second year } \\
10 / 1 / 76 \\
11 / 12 / 76\end{array}$ & $7.42^{\mathrm{a}}$ & $17.98^{b}$ & *2 & $12.58^{\mathrm{b}}$ & $*$ & $2.59^{\mathrm{a}}$ & 10.14 & 3.322 \\
\hline $\begin{array}{c}\text { Third year } \\
10 / 7 / 77 \\
11 / 17 / 77 \\
10 / 18 / 78\end{array}$ & $9.20^{\mathrm{a}}$ & $17.42^{\mathrm{a}}$ & * & $8.35^{\mathrm{a}}$ & * & * & 11.66 & 4.31 \\
\hline $\begin{array}{c}\text { Second year } \\
10 / 1 / 76 \\
11 / 12 / 76\end{array}$ & $7.10^{a}$ & $8.48^{\mathrm{a}}$ & $6.71^{a}$ & $4.79^{\mathrm{a}}$ & $2.59^{b}$ & $2.70^{b}$ & 5.39 & 0.959 \\
\hline $\begin{array}{c}\text { Third year } \\
10 / 7 / 77 \\
11 / 17 / 77 \\
10 / 18 / 78 \\
\end{array}$ & $32.78^{\mathrm{a}}$ & $28.36^{\mathrm{a}}$ & $20.75^{\mathrm{b}}$ & $19.75^{b}$ & $15.29^{\mathrm{h}}$ & $15.69^{\mathrm{b}}$ & 22.10 & 4.344 \\
\hline
\end{tabular}

Means in a row superscribed by the same letter are not significantly different at $\alpha=0.05$.

'arcsine transform of percent values.

${ }^{2}$ Negligible amounts or abscence. 
Fertilizer combination

\begin{tabular}{|c|c|c|c|c|c|c|c|}
\hline Plant species & $\begin{array}{c}\text { September } 25 \text {, } \\
1975 \\
0-0\end{array}$ & $0-0$ & $0-208$ & $\begin{array}{l}\text { vember } \\
1978 \\
381-0\end{array}$ & $381-208$ & $762-0$ & $762-208$ \\
\hline Dallisgrass & $V^{2} 1$ & $V^{2}$ & $\mathrm{~V}^{2}$ & $V^{2}$ & $v^{2}$ & $\mathrm{~V}^{3}$ & $V^{3}$ \\
\hline Phalaris aquarica & V' & IV & III $^{*}$ & $\mathrm{IV}^{2}$ & $V^{1}$ & $V^{2}$ & $v^{1}$ \\
\hline Piptochaetium bicolor & $\mathrm{V} \mathbf{1}$ & VI & $\mathrm{V}^{\prime}$ & $V^{2}$ & v' & $V^{2}$ & $V^{1}$ \\
\hline Stipa neesiana & IV! & $\mathbf{I}^{+}$ & $\mathrm{II}^{*}$ & $\mathbf{I}^{+}$ & $\mathrm{III}^{*}$ & $\mathrm{III}^{+}$ & III $^{+}$ \\
\hline Knotroot bristlegrass & III $^{1}$ & V! & $\mathbf{I I}^{1}$ & $\mathrm{~V}^{\prime}$ & II $^{1}$ & $\mathrm{III}^{2}$ & $11^{2}$ \\
\hline Prairie grass & $1^{+}$ & $1^{+}$ & 1 & $\mathrm{I}^{+}$ & III $^{+}$ & $\mathrm{I}^{+}$ & $11^{+}$ \\
\hline Black medic & $v^{\prime}$ & $111^{+}$ & $11 I^{1}$ & $\mathbf{I}^{+}$ & $\mathrm{II}^{+}$ & $* 2$ & $\mathrm{I}^{+}$ \\
\hline Gamochaeta spicata Cabr. & $*$ & $V^{\prime}$ & $\mathrm{V}^{+}$ & $v^{\prime}$ & vi & $\mathbf{V}^{+}$ & $v^{\prime}$ \\
\hline Hypochoeris spp. & $V^{\prime}$ & $V^{3}$ & $V^{3}$ & $\mathrm{~V}^{2}$ & $v^{2}$ & $\mathbf{V}^{2}$ & $V^{2}$ \\
\hline
\end{tabular}

IFrequency scale. V: $80.1-100 \%$ : IV: $60.1-80 \%$; 111:40.1-60\%; II: $20.1-40 \%$; I: up to $20 \%$.

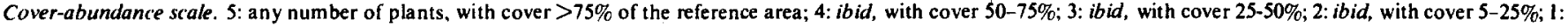
2Absent. numerous plants, but cover $<5 \%$; or scattered plants, with cover $\leqq 5 \%$; + : few plants, with small cover.

superphosphate tended to decrease the frequency values of knotroot bristlegrass (Setaria geniculata). The effect of the latter fertilizer was more intense than that of the former. Density, on the other hand, was markedly increased by the highest rate of ammonium sulphate, independently of superphosphate. These fertilizers did not modify greatly the species'density, which was lowest except in the plots fertilized with superphospate only.

At the time the last phytosociological survey was made black medic was the most conspicuous legume present in the grassland community. Its density was highest in the plots fertilized with superphosphate only.

The frequencies of Gamochaeta spicata and Hypochoeris spp. were not altered by fertilization: their respective densities, however, were modified to different extents. In fact, the coverabundance values of $G$. spicata seemed to be independent of fertilization, whereas those of Hypochoeris spp. were conspicuously decreased by ammonium sulphate.

The fluctuation of average $\mathrm{pH}$ values with depth was minimal, so that we present only the data for the upper $0.05 \mathrm{~m}$ as representative of the $0-0.2 \mathrm{~m}$ layer. We observed a definite decreasing effect of ammonium sulphate in the second year only (Table 5). Actually, the absence of the same trend in the third year was due to a strong interaction between ammonium sulphate and date of sampling. The interaction was due to seasonal effects on the magnitude - but not the sign-on the slope of the $\mathrm{pH}$-ammonium sulphate regression.

\section{Discussion}

The stimulating effect of fertilization on herbage production and, also, its modifying effect on the basic botanical composition of the "flechillar" were not surprising from a qualitative viewpoint. In fact those are well-documented effects of fertilizers, and particularly of those which contain nitrogen (Thurston 1969; Rogler and Lorenz 1974; Rabotnov 1977). The response of the "flechillar" to ammonium sulphate seemed to be conditioned by the sign of the water-balance in the soil. This balance was negative during the first year, and the value of ADMA was the lowest observed (cf. Figs. 2 and 3 ). When the soil water balance became almost null, the sward's overall dry matter accumulation and the response to fertilization were highest. If dry matter accumulation and fertilizer influence had depended solely on the amount of available water in the soil, dry matter accumulation in the third year would have been equal to or higher than that of the previous one because the soil water balance was positive and the site was not flooded at any time of the growing season. The difference lay in the changing response of grassland growth to ammonium sulphate; it shifted from linear to quadratic as time passed. Clearly, Mitscherlich's Law of Diminishing Returns was operating because some mineral nutrients in the soil must have become limiting for growth.

Although soil $\mathrm{pH}$ values may not have been faithful indicators of the true reaction of the soil solution (cf. Russell 1973), they were decreased to values as low as 4.1 in some sampling occasions. The a vailability of some of the major nutrients $=\mathrm{N}, \mathrm{P}, \mathrm{K}, \mathrm{S}, \mathrm{Ca}$, and $\mathrm{Mg}$ - becomes progressively lesser as soil $\mathrm{pH}$ decreases from $c a .5 .8$ downwards (cf. Buckman and Brady 1963). A glance at both the mean $\mathrm{pH}$ values and their corresponding ranges (Table 5) suggests that $\mathrm{pH}$ ind uced deficiencies of some nutrients, even of those added with the fertilizers, might have been brought about by ammonium sulphate hydrolysis as well as by its stimulating effect on plant growth.

Cogliatti (1978) found that the soil of this "flechillar" was deficient in $P$. In the field, however, regrowth did not respond regularly to triple superphosphate fertilization. When it did, it was immediately after the spring and autumn fertilizations in the second experimental year. It seems that the response to superphosphate was due to a strong demand for growth rather than to an actual deficiency of $\mathbf{P}$ in the soil.

Ammonium sulphate fertilization led to the elimination of the relatively small population of legumes. On the other hand, it poised the spread of other herbs, mainly rosette plants, through the stimulation of grass growth (cf. Tables 4 and 5). However, 3 years of chemical fertilization were insufficient for evoking well-defined

Table 5. Mean pH values for the upper 0.05-m soil layer of fertilized plots.

\begin{tabular}{lcccccccc}
\hline \hline & & \multicolumn{3}{c}{ Fertilizer combination } & & \\
Period & $0-0$ & $0-208$ & $381-0$ & $381-208$ & $762-0$ & $762-208$ & mean & S.E. \\
\hline Feb. 24, 1976- & $5.64^{\mathrm{a}}$ & $5.54^{\mathrm{a}}$ & $5.74^{\mathrm{a}}$ & $5.54^{\mathrm{a}}$ & $5.48^{\mathrm{a}}$ & $5.36^{\mathrm{a}}$ & 5.55 & 0.184 \\
Apr. 7, 1976 & $(5.2-6.1)^{\mathrm{a}}$ & $(5.1-6.4)$ & $(5.2-6.4)$ & $(5.1-5.9)$ & $(4.9-6.0)$ & & & \\
Sept. 25, 1976- & $5.99^{\mathrm{a}}$ & $5.84^{\mathrm{a}}$ & $5.84^{\mathrm{a}}$ & $5.74^{\mathrm{a}}$ & $5.56^{\mathrm{b}}$ & $5.45^{\mathrm{b}}$ & 5.74 & 0.112 \\
Apr. 24, 1977 & $(5.6-6.2)$ & $(5.5-6.2)$ & $(5.3-6.4)$ & $(5.1-6.1)$ & $(4.8-6.3)$ & $(4.75-6.1)$ & & \\
Oct. 7, 1977- & $5.85^{\mathrm{a}}$ & $5.71^{\mathrm{a}}$ & $5.63^{\mathrm{a}}$ & $5.51^{\mathrm{a}}$ & $5.41^{\mathrm{a}}$ & $5.12^{\mathrm{a}}$ & 5.54 & 0.343 \\
Oct. 18, 1978 & $(5.2-6.75)$ & $(5.1-6.55)$ & $(4.8-6.4)$ & $(4.6-6.4)$ & $(4.3-6.5)$ & $(4.1-6.45)$ & & \\
\hline
\end{tabular}

Means in a row superscribed by the same letter are not significantly different at $\alpha=0.05$.

'range. 
floristic changes in the "flechillar" (Table 4). If there were any, they might have been blurred because Braun-Blanquet's scales of frequency and cover-abundance are rather subjective and the plots were small for reasonably precise phytosociological surveys. Nevertheless, the spread and density of some specific populations varied very clearly. Ammonium sulphate increased the density of Dallisgrass, the most important warm-season component, and checked the expansion of the two most important hemicryptophytes of the community: Gamochaeta spicata and Hypochoeris spp. Apparently, these species were favored by the clipping regime although we do not know whether clipping modified the effect of fertilization on species dynamics.

The responsiveness of the "flechillar" to ammonium sulphate is indicative of responsiveness to nitrogen. This grassland's basic drawback is its low legume content, aggravated by the fact that its legume species are annuals whose growth may be severely impaired by any defoliation regime whereby their reseeding might be jeopardized. However if the "flechillar" were intersecded with perennial legumes, which establishment and growth should be aided by regular additions of some $P$ source, fertilization with chemical nitrogen would not be necessary altogether. This alternative has not been tested so far. If it were successful, it would be a way to increase forage production cheaper than the outright replacement of a "flechillar" by a cultivated pasture.

\section{Literature Cited}

Braun-Blanquet, J. 1950. "Sociología Vegetal: Estudio de las Comunidades Vegetales." (Translation of "Plant Sociology, the Study of Plant Communities." McGraw-Hill (1932). Acme Agency, Buenos Aires, 444 p.

Buckman, H.O., and N.C. Brady. 1963. "The Nature and Properties of Soils". 6th Edition. MacMillan, New York, 567 p.
Cogliatti, D. 1978. Respuesta de una comunidad de la "Depresión del Salado" a la fertilización nitrógeno-fosfatada. Rev. Fac. Agron. Univ. Centro Pcia. Buenos Aires (ln press).

Gates, C.E., and J.D. Bilbro 1978. llustration of a cluster analysis method of mean separation. Agron. J. 70:462-465.

Ginzo, H.D., Marta Collantes, and O.H. Caso. 1980. Ammonium sulphate and triple superphosphate fertilization of a halophytic native grassland in the "Depresión del Rio Salado", Province of Buenos Aires. Herbage dry matter accumulation and botanical composition. J. Range Manage. (Accepted).

Hodgson, J. 1979. Nomenclature and definitions in grazing studies. Grass and Forage Science 34:1 1-18.

Jackson, M.L. 1970. "Análisis químico de Suelos" (Translation of "Soil Chemical Analysis". Prentice-Hall, Inc.). Ediciones Omega. S.A. Barcelona. $662 \mathrm{p}$.

Rabotnov, T.A. 1977. The influence of fertilizers on the plant communities of mesophytic grasslands. $m$ : $\mathbf{W}$. Krause (ed.). "Application of Vegetation Science to Grassland Husbandry". Handbook of Vegetation Science-Vol. 13 p. 461-497. Dr. W. Junk, b.v. Publishers. The Hague.

Russell, E.W. 1973. Soil Conditions and Plant Growth. 10th Edition. Longman, London. 849 p.

Rogler, G.A., and R.J. Lorenz. 1974. Fertilization of mid-continent range plants. D.A. Mays (ed.) In: Forage Fertilization, p. 231-254. ASA, CSSA and SSSA Publishers. Madison.

Thornthwaite, C.W., and J.R. Mather. 1957. Instructions and tables for computing potential evapotranspiration and the water balance. Publications in Climatology. Vol. 10, No. 3, p. 185-311. Drexel Institute of Technology. Centerton, N. Jersey.

Thurston, J.M. 1969. The effect of liming and fertilizers on the botanical composition of permanent grassland, and on yield of hay. In: T.H. Rorison (ed.), Ecological Aspects of the Mineral Nutrition of Plants, p. 3-10. Blackwell Scientific Publications, Oxford

Vervoorst, F. 1967. "La Vegetación de la República Argentina. 7. Las Communidades Vegetales de la Depresión del Salado. (Pcia. de Buenos Aires)". Serie Fitogeográfica. INTA. Buenos Aires. 259 p. 